\title{
TELAAH FUNGSIONAL KONSEPSI INSENTIF TERHADAP KEPUASAN KERJA PEGAWAI
}

\author{
${ }^{1}$ Fahmiah Akilah, ${ }^{2}$ Danial Rahman \\ ${ }^{1}$ Institut Agama Islam Negeri (IAIN) Parepare, Jl. Amal Bhakti No. 8 Pare-pare, Indonesia \\ email: fahmiahakilah@iainparepare.ac.id \\ ${ }^{2}$ Pascasarjana UIN Alauddin Makassar, Jl. H.M. Yasin Limpo No. 36 Samata-Gowa, Indonesia \\ email: danial.rahman@uin-alauddin.ac.id
}

\begin{abstract}
Employee satisfaction of the suitability between the business and the outcome of his work is not necessarily felt by the employees, but not separated from the affect it. Employees will feel satisfied when their work is appreciated. The satisfaction felt by the employees can be determined by various factors, among them is giving incentives. Providing incentives will make employees feel the attention and recognition of achievements that are achieved so that the spirit of work and loyalty will be better. Employee will feel the satisfaction of his job if achievement achieved can be rewarded by giving incentives. Giving incentives to improve employee satisfaction does not only apply to organizations with profit, but also on nonprofit organizations (including educational institutions). Therefore, giving incentives is an important element that needs to be considered when trying to give satisfaction to the employees in their work.
\end{abstract}

Keywords: Incentive, Job Satisfaction, Employee Satisfaction

\section{PENDAHULUAN}

Sumber daya manusia merupakan sumber daya yang paling penting dalam organisasi karena melalui sumber daya manusia dapat menyebabkan sumber daya yang lain berfungsi dan dijalankan atau dilaksanakan sesuai dengan tujuan organisasi. Sumber daya manusia dapat menciptakan efisiensi, efektivitas dan produktivitas organisasi. Melalui sumber daya manusia yang efektif bisa menemukan cara terbaik untuk mencapai tujuan-tujuan organisasi yang diinginkan. Dengan demikian, salah satu faktor penting yang harus diperhatikan dan dioptimalkan perkembangannya oleh organisasi dalam mencapai tujuannya adalah faktor sumber daya manusia (SDM). Permasalahannya adalah bagaimana suatu lembaga dapat memiliki sumber daya manusia yang kompeten yang sesuai dengan peranan dan tugasnya sehingga dapat mendukung pencapaian tujuan lembaga organisasi tersebut.

Mok Er dan Rahman mengemukakan bahwa keberhasilan organisasi sangat tergantung pada peran manusia di dalamnya karena manusia sebagai sumber daya yang potensial dan merupakan sumber kekuatan untuk menggerakkan roda aktivitas. Oleh karena itu, sumber daya manusia harus diarahkan dan dikondisikan untuk menghasilkan kontribusi terbaik bagi organisasi sehingga tujuannya dapat terwujud. Lebih lanjut Mok Er \& Rahman mengemukakan bahwa setiap pegawai dalam organisasi memiliki karakteristik yang berbeda-beda sehingga tidak jarang ditemukan pegawai yang mempunyai keahlian atau kemampuan yang sama, tetapi memiliki 
keterampilan yang berbeda sehingga menghasilkan kinerja yang berbeda pula. ${ }^{1}$ Menurut Rosita \& Yuniati, faktor yang dapat meningkatkan kinerja sumber daya manusia di antaranya adalah kepuasan kerjanya. Faktor tersebut menjadi permasalahan yang penting untuk dicarikan solusi demi meningkatkan kinerja secara berkelanjutan. ${ }^{2}$ Diharapkan dengan semakin banyaknya pegawai yang mempunyai kinerja tinggi, produktivitas yang dihasilkan oleh suatu organisasi secara keseluruhan akan meningkat sehingga organisasi akan dapat bertahan dalam persaingan global. Oleh karena itu, pegawai dituntut untuk mampu menyelesaikan tugas dan tanggung jawabnya secara efektif dan efisien.

Kepuasan sebagai faktor yang dapat memengaruhi kinerja pegawai tentu tidak serta merta dirasakan oleh pegawai, tetapi tidak terlepas juga dari faktor yang memengaruhinya. Para pegawai akan merasa puas bila hasil kerja mereka dihargai. Akan tetapi, rasa puas itu tidak cukup untuk memacu semangat kerja mereka agar menghasilkan kinerja yang diharapkan karena mereka hanya akan mengejar target yang telah ditentukan oleh organisasi saja. Oleh karena itu, perlu adanya suatu imbalan yang diberikan bila mereka telah melewati target yang telah ditentukan oleh lembaga. Imbalan itu diberikan dalam bentuk uang agar mereka dapat menghasilkan kinerja lebih baik dari yang telah ditentukan oleh organisasi.

Kepuasan yang dirasakan oleh pegawai dalam melaksanakan pekerjaannya dapat ditentukan oleh berbagai faktor, diantaranya adalah pemberian insentif. Hal tersebut sebagaimana dikemukakan oleh Andini bahwa apabila pegawai tidak mendapatkan insentif yang baik dan nyaman dari pekerjaannya, maka kepuasan kerja mereka akan turun, absensi dan keterlambatan akan meningkat dan semakin sulit untuk bekerja sama dengan mereka atau mengadakan suatu perubahan penting. ${ }^{3} \mathrm{Hal}$ ini menunjukkan bahwa kepuasan kerja dari seseorang pegawai akan ikut menemukan kelangsungan operasional organisasi.

Permasalahan yang sering muncul adalah tidak adanya perhatian dari pengelola atau pimpinan suatu lembaga atau organisasi terhadap pemberian insentif kepada pegawai yang berprestasi atau yang mampu menyelesaikan tugasnya dengan baik. Hal tersebut dapat memberikan kurangnya motivasi kepada pegawai untuk terus berupaya meningkatkan kinerjanya karena kurangnya kepuasan yang dirasakan. Padahal, pemberian insentif yang diberikan oleh perusahaan atau lembaga kepada pegawai yang berprestasi tidak hanya membantu meningkatkan motivasi kerja pegawai yang memperoleh insentif tersebut, tetapi juga kepada seluruh pegawai yang ada.

1 Luqman Van Mok Er \& Danial Rahman, "Kinerja Pegawai di Kantor Kementerian Agama Kabupaten Bone (Analisis Komparatif berdasarkan Gender)", Jurnal Manajemen Pendidikan, Vol. 14 No. 2 (2019), h. 137-143.

2 Titik Rosita dan Tri Yuniati, "Pengaruh Kepuasan Kerja terhadap Kinerja Karyawan dengan Komitmen Organisasional sebagai Variabel Intervening”, Jurnal Riset dan Ilmu Manajemen, Vol. 5 No. 1 (2016), h. 1-20.

${ }^{3}$ Shelvia Putri Andini, "Pengaruh Insentif dan Lingkungan Kerja terhadap Kepuasan Kerja Karyawan pada AJB Bumiputera 1912 KPR Pekanbaru”, JOM FISIP, Vol. 4 No. 1 (2017), h. 1-15. 
Mereka akan termotivasi untuk berusaha menampilkan kinerja yang baik jika memiliki ada sesuatu hal yang dapat mendorongnya, termasuk pemberian insentif tersebut. Oleh karena itu, tulisan ini hadir untuk memberikan pemahaman kepada pimpinan atau pengelola suatu lembaga atau organisasi untuk lebih memerhatikan kepuasan kerja pegawainya dengan memberikan insentif terhadap prestasi kerja yang dicapainya.

\section{Pengertian dan Pentingnya Pemberian Insentif}

Insentif merupakan bagian dari kompensasi. Kompensasi merupakan segala sesuatu yang diberikan oleh lembaga atau organisasi kepada pegawai karena telah memberikan sumbangan berupa tenaga dan pikiran demi kemajuan untuk mencapai tujuan yang telah ditetapkan oleh lembaga atau organisasi yang bersangkutan. ${ }^{4}$ Hal tersebut mengindikasikan bahwa terminologi kompensasi merujuk pada konsep yang lebih luas. Konsep kompensasi berhubungan dengan segala imbalan yang diterima oleh orang-orang melalui hubungan kepegawaian mereka. Dengan demikian, kompensasi dapat mencakup gaji, upah, insentif, maupun tunjangan. Namun, pembahasan dalam tulisan ini lebih spesifik pada pemberian insentif kepada pegawai.

Insentif menurut Dessler adalah imbalan keuangan yang dibayarkan kepada pekerja yang produksinya melebihi standar yang ditetapkan sebelummya. ${ }^{5}$ Lebih lanjut dikemukakan oleh Samsudin bahwa insentif merupakan pemberian upah atau gaji yang berbeda, bukan didasarkan pada evaluasi jabatan, tetapi karena adanya perbedaan prestasi kerja. ${ }^{6}$ Sementara insentif menurut Veithzal Riva'i merupakan bentuk pembayaran yang dikaitkan dengan kinerja dan gainsharing sebagai pembagian keuntungan bagi karyawan akibat peningkatan produktivitas atau penghematan biaya. ${ }^{7}$ Lebih lanjut Mangkunegara mendefinisikan insentif sebagai suatu penghargaan dalam bentuk uang yang diberikan oleh pihak pemimpin organisasi kepada pegawai agar mereka bekerja dengan motivasi yang tinggi dan berprestasi dalam mencapai tujuan-tujuan organisasi. Dengan kata lain, insentif merupakan pemberian uang di luar gaji yang dilakukan oleh pihak pemimpin organisasi sebagai pengakuan terhadap prestasi kerja dan kontribusi karyawan organisasi. ${ }^{8}$

Beberapa pendapat tersebut mengindikasikan bahwa insentif berbeda dengan gaji karena insentif diberikan berdasarkan prestasi kerja bukan sesuatu yang diberikan secara periodik, berbeda pula dengan upah karena bukan imbalan yang diberikan berdasarkan jumlah satuan pekerjaan yang dibayarkan setelah diselesaikan. Selain itu, insentif juga berbeda dengan tunjangan karena insentif

\footnotetext{
${ }^{4}$ Nurul Ulfatin dan Teguh Triwiyanto, Manajemen Sumber Daya Manusia Bidang Pendidikan (Cet. I; Jakarta: Rajawali Pers, 2016), h. 120.

${ }^{5}$ Gary Dessler, Manajemen Sumber Daya Manusia, terj. Benyamin Molan (Jakarta: RajaGrafindo Persada, 2009), h. 66.

${ }^{6}$ Sadili Samsudin, Manajemen Sumber Daya Manusia (Cet. I; Bandung: Pustaka Setia, 2006), h. 194.

7 Veithzal Rivai, Manajemen Sumber Daya Manusia untuk Perusahaan dari Teori ke Praktek (Jakarta: Murai Kencana, 2005), h. 384.

8 A.A. Anwar Prabu Mangkunegara, Manajemen Sumber Daya Manusia Perusahaan (Cet. XII; Bandung: Remaja Rosdakarya, 2015), h. 89.
} 
diberikan secara langsung sementara tunjangan diberikan secara tidak langsung berdasarkan kebutuhan kerja pegawai, berbeda pula dengan bonus karena insentif diberikan atas prestasi kerja, bukan atas keuntungan lebih yang diperoleh perusahaan. Sebagai ilustrasi, terdapat dua orang pegawai dengan jabatan yang sama dan gaji yang sama, tetapi memiliki insentif yang berbeda karena adanya perbedaan prestasi kerja.

Fungsi utama dilakukannya pemberian insentif adalah untuk memberikan dorongan dan tanggung jawab kepada pegawai dalam memperbaiki kualitas dan kuantitas hasil kerjanya agar lebih termotivasi dan lebih meningkatkan prestasi kerjanya. Adapun tujuan utama pemberian insentif adalah untuk meningkatkan produktivitas kerja individu maupun kelompok, meningkatkan penghasilan lebih besar, dan bagi perusahaan atau instansi lain untuk mendapatkan biaya per-unit lebih rendah.

Handoko mengemukakan bahwa tujuan pemberian insentif adalah untuk meningkatkan motivasi pegawai dalam upaya mencapai tujuan-tujuan organisasi dengan menawarkan perangsang finansial di atas dan melebihi upah dan gaji dasar. ${ }^{9}$ Oleh karena itu, dapat disimpulkan bahwa pemberian insentif yang dilakukan harus dapat memuaskan kedua belah pihak, yaitu sisi perusahaan dan dari sisi pegawai. Dengan demikian, pemberian insentif ini dapat meningkatkan semangat kerja pegawai sehingga dapat dikatakan bahwa insentif merupakan suatu alat perangsang atau pendorong yang diberikan agar dapat lebih berprestasi dalam menghasilkan kinerja yang lebih baik.

Tujuan pemberian insentif sering kali gagal sehingga diperlukan langkah-langkah yang efektif dalam penentuannya. Menurut Panggabean sebagaimana yang dikutip dari Cascio mengemukakan bahwa langkah-langkah penentuan insentif yang efektif meliputi: 1) penentuan standar prestasi kerja; 2) pengembangan sistem penilaian prestasi; 3) melatih penyelia dalam melakukan penilaian prestasi dan dalam memberikan umpan balik kepada bawahannya; 4) menghubungkan penghargaan dengan prestasi kerja; 5) mengupayakan agar peningkatan penghargaan ada artinya bagi karyawan. ${ }^{10}$

Suwatno dan Priansa mengemukakan bahwa insentif sebagai suatu perangsang minat untuk bekerja dapat meliputi insentif material dan insentif nonmaterial. ${ }^{11}$ Lebih lanjut, Hasibuan menambahkan bahwa bentuk-bentuk insentif dibedakan menjadi: nonmaterial insentif, social insentif, dan material insentif. ${ }^{12}$ Nonmaterial insentif merupakan daya perangsang yang diberikan

\footnotetext{
${ }^{9}$ T. Hani Handoko, Manajemen Personalia dan Sumber Daya Manusia (Yogyakarta: BPFE, 2008), h. 176.

${ }^{10}$ S. Mutiara Panggabean, Manajemen Sumber Daya Manusia (Jakarta: Ghalia Indonesia, 2004), h. 90.

11 Suwatno dan Donni Juni Priansa, Manajemen SDM dalam Organisasi Publik dan Bisnis (Bandung: Alfabeta, 2011), h. 234.

${ }_{12}$ Malayu S.P. Hasibuan, Manajemen Sumber Daya Manusia (Cet. XXI; Jakarta: Bumi Aksara, 2017), h. 184-185.
} 
kepada pegawai berbentuk penghargaan atau pengukuhan berdasarkan prestasi kerjanya, seperti piagam, piala, atau medali. Social insentif merupakan daya perangsang yang diberikan kepada pegawai berdasarkan prestasi kerjanya, berupa fasilitas dan kesempatan untuk mengembangkan kemampuannya, seperti promosi, mengikuti pendidikan, atau menunaikan haji. Material insentif merupakan daya perangsang yang diberikan kepada pegawai berdasarkan prestasi kerjanya, berbentuk uang dan barang. Material ini bernilai ekonomis sehingga dapat meningkatkan kesejahteraan karyawan beserta keluarganya. Dengan demikian, berdasarkan pendapat Hasibuan tersebut menandakan bahwa insentif tidak hanya dalam bentuk materi (uang atau barang), tetapi juga dapat dalam bentuk nonmaterial dan social insentif.

Metode pemberian insentif yang layak kepada pegawai merupakan daya penggerak yang merangsang terciptanya pemeliharaan pegawai. Pemberian insentif akan membuat pegawai merasa mendapatkan perhatian dan pengakuan terhadap prestasi yang dicapainya sehingga semangat kerja dan loyalitasnya akan lebih baik. Namun demikian, pemberian insentif tidak hanya diberikan kepada yang berprestasi, tetapi juga kepada pegawai yang berprestasi kurang baik. Hasibuan mengistilahkan bahwa pemberian insentif kepada pegawai yang berprestasi dinamakan insentif positif yang dapat berupa material maupun nonmaterial, sedangkan pemberian insentif kepada pegawai yang kurang berprestasi dinamakan insentif negatif, seperti memberikan ancaman hukuman kepada pegawai. ${ }^{13}$

Berdasarkan uraian tersebut di atas, dapat dipahami bahwa pemberian insentif kepada pegawai merupakan hal yang perlu diperhatikan oleh lembaga atau pimpinan karena menjadi daya penggerak bagi pegawai untuk meningkatkan motivasi dan semangat kerjanya sehingga dapat melahirkan kepuasan dan pada akhirnya berdampak pada kinerjanya yang baik pula. Dengan demikian, insentif sebagai tambahan penghasilan di luar gaji atau upah menjadi metode dalam meningkatkan loyalitas pegawai karena merasa diperhatikan dan dihargai jasa-jasanya dalam suatu lembaga atau organisasi.

\section{Kepuasan Kerja Melalui Pemberian Insentif}

Kepuasan kerja dapat dikatakan sebagai perasaan senang atau tidak senang yang bersifat relatif. Kepuasan kerja ini berbeda dari pemikiran objektif dan keinginan perilaku karena perasaan terkait dengan sikap seseorang. Oleh karena itu, kepuasan kerja dapat didefinisikan sebagai suatu sikap pegawai yang timbul berdasarkan penilaian terhadap situasi di tempat mereka bekerja. Secara sederhana, kepuasan kerja dapat dikatakan sebagai pegawai yang memiliki kepuasan atas pekerjaannya. Sebaliknya, ketidakpuasan akan muncul apabila salah satu atau sebagian dari kebutuhannya tidak terpengaruhi. Lebih lanjut, Andini mengemukakan bahwa kepuasan kerja

\footnotetext{
${ }^{13}$ Ibid., h. 185.
} 
merupakan salah satu komponen dari kepuasan hidup sehingga menjadi hal yang penting untuk memperhatikan dalam pengembangan dan pemeliharaan tenaga kerja. ${ }^{14}$

Kepuasan kerja merupakan sikap emosional yang menyenangkan dan mencintai pekerjaannya. Sikap ini dicerminkan oleh moral kerja, kedisiplinan dan prestasi kerja. Kepuasan kerja dinikmati dalam pekerjaan, luar pekerjaan, dan kombinasi dalam dan luar pekerjaan. ${ }^{15} \mathrm{Hal}$ ini tampak pada sikap positif karyawan terhadap pekerjaan dan segala sesuatu yang dihadapi di lingkungan kerjanya. ${ }^{16}$ Handoko juga mengemukakan bahwa kepuasan kerja adalah keadaan emosional yang menyenangkan atau tidak menyenangkan dengan mana para pegawai memandang pekerjaan mereka. Kepuasan kerja mencerminkan perasaan seseorang terhadap pekerjaannya. ${ }^{17}$

Kepuasan kerja menurut Stephen P. Robbins adalah suatu sikap umum individu terhadap pekerjaannya. Menurutnya, seseorang dengan kepuasan kerja tinggi akan menunjukkan sikap positif terhadap pekerjaannya, begitu pula sebaliknya seseorang yang tidak puas dengan pekerjaannya akan menunjukkan sikap yang negatif terhadap pekerjaannya. ${ }^{18}$ Sementara Keith Davis sebagaimana dikutip oleh Mangkunegara mengemukakan bahwa job satisfaction is the favorableness or unfavorableness with employees view their work. Lebih lanjut Wexley dan Yuki mendefinisikan kepuasan kerja sebagai the way an employee feels about his or her job. ${ }^{19}$ Pernyataan tersebut berarti bahwa kepuasan kerja adalah perasaan menyokong atau tidak menyokong yang dialami pegawai dalam bekerja atau cara pegawai merasakan dirinya maupun pekerjaannya. Perasaan pegawai yang berhubungan dengan pekerjaan melibatkan aspek upah atau gaji yang diterima, kesempatan jenis pekerjaan, struktur organisasi, mutu pengawasan. Adapun perasaan yang berhubungan diri pegawai antara lain umur, kondisi kesehatan, kemampuan, pendidikan.

Teori yang terkait dengan kepuasan kerja pegawai adalah teori dua faktor yang dikembangkan oleh Frederick Herzberg. Dua faktor yang dapat menyebabkan timbulnya rasa puas atau tidak puas menurut Hezberg adalah faktor pemeliharaan (maintenance factors) dan faktor pemotivasian (motivational factors). Faktor pemeliharaan meliputi administrasi dan kebijakan lembaga, kualitas pengawasan, hubungan dengan pengawas, hubungan dengan subordinate, upah, keamanan kerja, kondisi kerja, dan status. Sementara faktor pemotivasian dapat meliputi dorongan berprestasi, pengenalan, kemajuan, work it self, kesempatan berkembang, dan tanggung jawab.

${ }^{14}$ Shelvia Putri Andini, "Pengaruh Insentif dan Lingkungan Kerja terhadap Kepuasan Kerja Karyawan pada AJB Bumiputera 1912 KPR Pekanbaru”, JOM FISIP, Vol. 4 No. 1 (2017), h. 1-15.

${ }^{15}$ Hasibuan, Manajemen Sumber Daya Manusia, h. 8.

${ }^{16}$ Danang Sunyoto, Teori, Kuesioner, dan Analisis Data Sumber Daya Manusia (Praktik Penelitian) (Cet. I; Yogyakarta: CAPS, 2012), h. 26.

${ }^{17}$ Handoko, Op. Cit., h. 18.

${ }^{18}$ Stephen P. Robbins, Perilaku Organisasi, terj. Benyamin Molan (Cet. II; Jakarta: Indeks, 2007), h. 94 .

\footnotetext{
${ }^{19}$ Mangkunegara, Op. Cit., h. 117.
} 
Luthans menyatakan terdapat lima faktor yang mempengaruhi kepuasan kerja, yaitu: work it self, supervision, promotion, pay, dan coworkers. ${ }^{20}$ Pekerjaan (Work itself) adalah sifat menyeluruh dari pekerjaan itu sendiri yang merupakan factor penentu utama dalam kepuasan kerja. Pekerjaan mempengaruhi kepuasan kerja melalui rancangan jabatan. Pekerjaan itu dipengaruhi oleh elemen-elemen seperti skill variety, task identity, task significant, autonomy and feedback dari pekerjaan itu sendiri yang memberikan kontribusi terhadap kepuasan kerja. Atasan (Supervision) merupakan pengawasan langsung yang dilaksanakan oleh seorang atasan terhadap hasil pekerjaan yang dilakukan oleh bawahannya supervisor yang baik harus mau menghadapi pekerjaan bawahnya dan dapat menjadi figur yang disenangi oleh bawahannya. Promosi (Promotion) adalah perpindahan pegawai dari satu jabatan ke jabatan yang lain yang mempunyai tingkatan organisasional, tanggung jawab dan pembayaran yang lebih tinggi. Upah atau gaji (Pay) dapat diartikan sebagai balas jasa berupa uang yang diberikan perusahaan kepada seorang pegawai sebagai imbalan atas tenaga, pemikiran dan waktu yang telah diberikan kepada perusahaan. Kondisi kerja (Coworkers) merupakan interaksi sosial yang terjadi antara sesama rekan sekerja dalam lingkungan pekerjaan baik sebagai sesama pekerja, atasan dan bawahan dan antara rekan sekerja yang berbeda jenis pekerjaannya.

Berdasarkan uraian tersebut, dapat diketahui bahwa salah satu faktor kepuasan kerja adalah pay (upah/gaji). Namun, perlu dipahami bahwa gaji saja tidak cukup sebagai imbalan balas jasa yang sifatnya periodik dapat mempertahankan atau meningkatkan motivasi kerja pegawai untuk mencapai kinerja yang lebih baik. Tetapi, perlu adanya penghargaan terhadap prestasi yang dicapai oleh pegawai. Dengan begitu, pegawai akan semakin meningkatkan motivasinya untuk bekerja dengan giat karena ada faktor lain berupa imbalan di luar gaji jika dapat mencapai prestasi kerja yang baik sehingga melahirkan sikap atau perasaan puas terhadap hasil kerja dan imbalan yang diterimanya. Beberapa penelitian yang telah membuktikan adanya pengaruh insentif terhadap kepuasan kerja pegawai, di antaranya akan diurai sebagai berikut.

Putri Andini dalam penelitiannya membuktikan bahwa insentif yang diberikan berpengaruh signifikan terhadap kepuasan kerja pegawai. Andini kemudian menyimpulkan bahwa semakin perusahaan atau lembaga dapat meningkatkan insentif yang positif maka akan mempengaruhi kepuasan kerja pegawai. ${ }^{21}$ Penelitian lain yang telah dilakukan oleh Kurniawan yang dilakukan dengan menguji pengaruh insentif dan pengembangan karir terhadap kepuasan kerja melalui kinerja pegawai menunjukkan bahwa berdasarkan analisis SEM terbukti bahwa insentif memiliki

${ }^{20}$ Fred Luthans, Perilaku organisasi (Yogyakarta: Penerbit ANDI, 2006), h. 76.

${ }^{21}$ Shelvia Putri Andini, "Pengaruh Insentif dan Lingkungan Kerja terhadap Kepuasan Kerja Karyawan pada AJB Bumiputera 1912 KPR Pekanbaru”, JOM FISIP, Vol. 4 No. 1 (2017), h. 1-15. 
pengaruh terhadap kepuasan kerja, bahkan lebih besar dari pengaruh pengembangan karir. ${ }^{22}$ Kedua penelitian tersebut memberikan indikasi bahwa insentif merupakan aspek penting dalam memberikan rasa puas kepada pegawai terhadap hasil kerjanya.

Berbeda dengan penelitian di atas, penelitian Zaputri, dkk. menguji pengaruh insentif dengan melihat masing-masing pengaruh insentif material dan insentif nonmaterial. Hasil penelitian mereka menunjukkan bahwa berdasarkan analisis path yang dilakukannya, terbukti bahwa variabel insentif material dan nonmaterial berpengaruh langsung terhadap kepuasan kerja pegawai. ${ }^{23}$ Lebih lanjut, penelitian yang dilakukan oleh Navika Sari dan Irwanto yang juga membuktikan bahwa insentif material dan insentif nonmaterial berpengaruh secara simultan terhadap kepuasan kerja pegawai. ${ }^{24}$ Penelitian lain juga dilakukan oleh Satriani, dkk. yang meneliti kepuasan kerja perawat pada salah satu rumah sakit membuktikan bahwa insentif berpengaruh secara positif terhadap kepuasan kerja perawat meskipun hasilnya tidak signifikan. ${ }^{25}$

Kepuasan terhadap pemberian insentif juga dirasakan oleh pegawai pada lembaga pendidikan, dalam hal ini guru. Hal tersebut sebagaimana dibuktikan oleh Djamroni melalui penelitiannya bahwa terdapat pengaruh positif dan signifikan pemberian insentif terhadap kepuasan kerja guru. ${ }^{26}$ Lebih lanjut, Budianto dan Istanto yang juga telah membuktikan melalui penelitiannya bahwa terdapat pengaruh positif pemberian insentif terhadap kepuasan kerja guru. ${ }^{27}$ Hal ini menandakan bahwa semakin tinggi pemberian insentif yang diberikan oleh instansi atau pimpinan kepada guru, semakin tinggi pula tingkat kepuasan kerja guru. Oleh karena itu, pemberian insentif menjadi alternatif yang dapat digunakan dalam meningkatkan kepuasan pegawai terhadap pekerjaannya yang tentu akan merasa dihargai atas prestasi yang dicapainya.

${ }^{22}$ Anton Kurniawan, "Pengaruh Insentif dan Pengembangan Karir terhadap Kepuasan Kerja melalui Kinerja Karyawan sebagai Variable Intervening/Moderating pada AJB Asuransi Bumiputera 1912 Palembang", Jurnal Ilmu Manajemen, Volume 14 Nomor 1 (2016), h. 48-66.

${ }^{23}$ Anggi Rizki Zaputri, Kusdi Rahardjo, dan Hamida Nayati Utami, "Pengaruh Insentif Material dan Non-Material terhadap Kepuasan Kerja dan Kinerja Karyawan (Studi pada Karyawan Produksi Cetak PT. Temprina Media Grafika di Surabaya), h. 1-8.

${ }^{24}$ Rahmawati Navika Sari dan Dodi W. Irwanto, "Pengaruh Insentif Terhadap Kepuasan Kerja Karyawan (Studi pada PG Kebon Agung Malang)", h. 1-11.

${ }^{25}$ Satriani, Rasyidin Abdullah, dan Budiman Harun, "Pengaruh Pendidikan dan Pelatihan (Diklat) serta Insentif terhadap Kepuasan Kerja Perawat melalui Motivasi Kerja di Ruang Rawat Inap Rumah Sakit Arifin Nu'mang Kabupaten Sidenreng Rappang”, YUME: Journal of Management, Volume 2 Nomor 3 (2019).

${ }^{26}$ Djamroni, "Pengaruh Pemberian Insentif dan Profesionalisme Guru terhadap Kepuasan Kerja Guru SMP Swasta di Kota Tangerang", TANZHIM: Jurnal Penelitian Manajemen Pendidikan, Volume 1 Nomor 2 (2016), h. 45-61.

27 Adit Budianto dan Istanto, "Pengaruh Pemberian Insentif, Kondisi Lingkungan Kerja dan Kepemimpinan Kepala Sekolah terhadap Kepuasan Kerja Guru di SMK Tamansiswa Kota Yogyakarta", ELEKTRO: E-Journal Universitas Negeri Yogyakarta, Volume 3 Nomor 3 (2014), h. 198-205. 


\section{KESIMPULAN}

Metode pemberian insentif yang layak kepada pegawai merupakan daya penggerak yang merangsang terciptanya pemeliharaan pegawai. Pemberian insentif akan membuat pegawai merasa mendapatkan perhatian dan pengakuan terhadap prestasi yang dicapainya sehingga semangat kerja dan loyalitasnya akan lebih baik. Berdasarkan beberapa bukti teoretis dan empiris tentang kepuasan kerja pegawai melalui pemberian insentif, dapat dipahami bahwa pegawai akan merasakan kepuasan terhadap pekerjaannya jika prestasi yang dicapai dapat dihargai dengan memberikan insentif. Pemberian insentif dalam meningkatkan kepuasan kerja pegawai tidak hanya berlaku dalam organisasi yang sifatnya profit, tetapi juga pada organisasi-organisasi nonprofit (termasuk di dalamnya lembaga pendidikan). Oleh karena itu, pemberian insentif merupakan unsur penting yang perlu diperhatikan ketika hendak memberikan rasa puas kepada para pegawai dalam pekerjaannya. Meskipun demikian, pemberian insentif bukan sebagai satu-satunya cara meningkatkan kepuasan kerja pegawai, tetapi dapat menjadi alternatif yang efektif dilakukan sebagai bentuk penghargaan atas prestasi kerja yang dicapai oleh pegawai.

\section{DAFTAR RUJUKAN}

Andini, Shelvia Putri. "Pengaruh Insentif dan Lingkungan Kerja terhadap Kepuasan Kerja Karyawan pada AJB Bumi Putera 1912 KPR Pekanbaru." JOM FISIP 4, no. 1 (Februari 2017)

Dessler, Gary. Manajemen Sumber Daya Manusia. Dialihbahasakan oleh Benyamin Molan. Jakarta: RajaGrafindo Persada, 2009.

Djamroni. "Pengaruh Pemberian Insentif dan Profesionalisme Guru terhadap Kepuasan Kerja Guru SMP Swasta di Kota Tangerang." TANZHIM: Jurnal Penelitian Manajemen Pendidikan 1, no. 2 (2016)

Er, Luqman Van Mok, dan Danial Rahman. "Kinerja Pegawai di Kantor Kementerian Agama Kabupaten Bone (Analisis Komparatif berdasarkan Gender)." Jurnal Manajemen Pendidikan 14, no. 2 (2019)

Handoko, T. Hani. Manajemen Personalia dan Sumber Daya Manusia. Yogyakarta: BPFE, 2008.

Hasibuan, Malayu S.P. Manajemen Sumber Daya Manusia. Jakarta: Bumi Aksara, 2017.

Istanto, Adit Budianto. "Pengaruh Pemberian Insentif, Kondisi Lingkungan Kerja dan Kepemimpinan Kepala Sekolah terhadap Kepuasan Kerja Guru di SMK Tamansiswa Kota Yogyakarta.” ELEKTRO: E-Journal Universitas Negeri Yogyakarta 3, no. 3 (2014)

Kurniawan, Anton. "Pengaruh Insentif dan Pengembangan Karir terhadap Kepuasan Kerja melalui Kinerja Karyawan sebagai Variable Intervening/Moderating pada AJB Asuransi Bumiputera 1912 Palembang." Jurnal Ilmu Manajemen 14, no. 1 (2016)

Luthans, Fred. Perilaku organisasi. Yogyakarta: Penerbit ANDI, 2006.

Mangkunegara, A.A. Anwar Prabu. Manajemen Sumber Daya Manusia Perusahaan. Bandung: Remaja Rosdakarya, 2015. 
Panggabean, S. Mutiara. Manajemen Sumber Daya Manusia. Jakarta: Ghalia Indonesia, 2004.

Rivai, Veithzal. Manajemen Sumber Daya Manusia untuk Perusahaan dari Teori ke Praktek. Jakarta: Murai Kencana, 2005.

Robbins, Stephen P. Perilaku Organisasi. Dialihbahasakan oleh Benyamin Molan. Jakarta: Indeks, 2007.

Rosita, Titik, dan Tri Yuniati. "Pengaruh Kepuasan Kerja terhadap Kinerja Karyawan dengan Komitmen Organisasional sebagai Variabel Intervening." Jurnal Ilmu dan Riset Manajemen 5, no. 1 (2016)

Samsudin, Sadili. Manajemen Sumber Daya Manusia. Pustaka Setia: Bandung, 2006.

Sari, Rahmawati Navika, dan Dodi W. Irwanto. "Pengaruh Insentif Terhadap Kepuasan Kerja Karyawan (Studi pada PG Kebon Agung Malang).” t.thn.

Satriani, Rasyidin Abdullah, dan Budiman Harun. "Pengaruh Pendidikan dan Pelatihan (Diklat) serta Insentif terhadap Kepuasan Kerja Perawat melalui Motivasi Kerja di Ruang Rawat Inap Rumah Sakit Arifin Nu'mang Kabupaten Sidenreng Rappang." YUME: Journal of Management 2, no. 3 (2019).

Sunyoto, Danang. Teori, Kuesioner, dan Analisis Data Sumber Daya Manusia (Praktik Penelitian). Yogyakarta: CAPS, 2012.

Suwatno, dan Donni Juni Priansa. Manajemen SDM dalam Organisasi Publik dan Bisnis. Bandung: Alfabeta, 2011.

Ulfatin, Nurul, dan Teguh Triwiyanto. Manajemen Sumber Daya Manusia Bidang Pendidikan. Jakarta: Rajawali Pers, 2016.

Zaputri, Anggi Rizki, Kusdi Rahardjo, dan Hamida Nayati Utami. "Pengaruh Insentif Material dan Non-Material terhadap Kepuasan Kerja dan Kinerja Karyawan (Studi pada Karyawan Produksi Cetak PT. Temprina Media Grafika di Surabaya)." t.thn. 